\title{
Assessment of Clonal Fidelity and Genetic Analysis of Tissue Culture Raised Banana (Musa spp.) Plant
}

\author{
Jotshana Manik Maske ${ }^{1^{*}}$, Amol Dadarao Sable ${ }^{1}$ and Prashant Bhausaheb Kardile ${ }^{2}$ \\ ${ }^{1}$ Department of Plant Biotechnology, SDMVM's College of Agricultural Biotechnology, \\ Georai Tanda, Paithan Road, Aurangabad (M.S.)-431001, India \\ ${ }^{2}$ Department of Agricultural Botany, Dadasaheb Patil College of Agriculture, Dahegaon, \\ Auranagabad (M.S.)-423715, India
}

*Corresponding author

\begin{abstract}
A B S T R A C T
Banana (Musa spp.) is important fruit crop in India. Banana is one of the oldest and most popular fruit grown in India with great socio-economic significance. The present study

Keywords

Banana, Clonal Fidelity, RAPD, Primer

Article Info

Accepted:

20 March 2018

Available Online:

10 April 2018 aims to assessment of clonal fidelity and genetic analysis of tissue culture raised banana (Musa spp.) plant. Banana tissue culture propagation is a new an established a popular technology due to the advantages. Through plant tissue culture method large scale production is possible in short time. The most reliable methods are the molecular marker techniques that identify the variance depending on the plant proteins, which are expressed from defined regions of DNA, or DNA polymorphisms. RAPD (random amplified polymorphic DNA's) is a powerful technique for identification of genetic variation (Welsh et al., 1990). The RAPD technique is effective to develop genotype-specific banding patterns valuable for cultivar identification. Molecular analysis using RAPD's can be applied to assess the clonal fidelity of plants derived in-vitro on an industrial scale as part of crop improvement programs. With the primer OPA-19 and OPC-1 amplified 1 mother and 4 daughter subculture are showed polymorphic bands is seen range of $500 \mathrm{bp}$ to $1000 \mathrm{pb}$.
\end{abstract}

\section{Introduction}

Banana (Musa spp.) is important fruit crop in India. Banana is one of the oldest and most popular fruit grown in India with great socioeconomic significance. The scientific name of banana is Musa accuminata. Banana fruit crop is belongs to the family Musaceae. The native of banana is Southeast Asia. Leading banana producing state in India is Tamilnadu followed by Maharashtra. All India average production is about 34.30 metric tonnes. Banana is very popular fruit due to its low price and high nutritive value it is consumed in fresh or cooked from both as ripe and raw fruit. Banana is traditionally propagated through sucker method. Suckering shrubs such as aronia, bay, species, roots can send up new shoot or sucker from their root. Remove and growing on thus shoot with roots at their base 
is an easily and low cost way to produce new plants. Establishment is usually is main problem very careful water is needed for the first season or roots of the suckers are not well developed. The conventional method means the multiplication is too slow and quality of fruit is less irregular flowering and variant harvesting time also claimed in this method. As a current demand of consumers of banana would not be fulfill with traditional cultivation. Need to develop rapid multiplication and quality planting material.

Banana tissue culture propagation is a new an established a popular technology due to the advantages. Through plant tissue culture method large scale production is possible in short time It offers such as commercial production of disease free planting materials comparatively unique plant stand in the field, early harvesting of superior fruit bunches round the year availability of the planting material.

However, the true to type of plant is most important for the commercial banana, while using this method it would be possible the genetic variation in several ways. It needs to assessment the genetic stability in planting using in various molecular marker and techniques.

The PCR based molecular markers such RAPD, ISSR, SSR, were used for the genetic assessment in different crop among these markers RAPD is most reliable. Advantages of RAPD markers is, it's a reproducible marker and processed by an efficiency inexpensive technique without requiring prior knowledge of the genome. RAPD assay has the advantage of being easy to use, requiring small amount of DNA without the need for blotting.

The most reliable methods are the molecular marker techniques that identify the variance depending on the plant proteins, which are expressed from defined regions of DNA, or DNA polymorphisms.

\section{Materials and Methods}

The present study "Assessment of clonal fidelity and genetic analysis of tissue culture raised banana (Musa spp.) Plant" was carried out at Department of Plant Biotechnology SDMVM's College of Agricultural Biotechnology, Georai Tanda, Paithan Road, Aurangabad (M.S.), 431001, during Jan-2016 to March -2016, with objects 1. To extract DNA from Banana leaf sample. 2. To check clonal fedility and genetic analysis of tissue culture raised banana (Musa spp.) plant.

\section{Source of explants}

The source of explants is variety used G-9.

\section{Methodology}

\section{Reagents used for the DNA isolation}

$\beta$-mercaptoethanol (added at the time of used)

Potassium Acetate

Chloroform: Isoamyl alchohol (24:1)

$100 \%$ Isopropanol (ice-cold)

Wash Buffer: 70\% Ethanol

RNAse

TE-Buffer $(10 \mathrm{Mm}$ Tris base And $1 \mathrm{mM}$ EDTA) pH8.0

\section{Gel electrophoresis}

Purity of isolated DNA was checked with agarose (1\%) gel electrophoresis and quantity by nanodrop spectrophotometer. 


\section{RAPD analysis}

The quality of DNA, obtained by various protocols and subjected to various storage conditions can be judged by comparing the PCR amplification profiles.

The most commonly used technique that can be accessed by almost any laboratory is RAPD. Random amplified polymorphic DNA (RAPD) is a PCR based technique for identifying genetic variation.

It involves the use of a single arbitrary primer in a PCR reaction, resulting in the amplification of many discrete DNA products. The technique was developed independently by two different laboratories (Williams et al., 1990; Welsh and McClelland, 1990) and called as RAPD and AP-PCR (Arbitrary primed PCR) respectively.

\section{PCR reaction}

\section{Procedure for $\mathrm{PCR}$ reaction}

Master mixture $(240 \mu \mathrm{l})$ was prepared in 1.5 $\mathrm{ml}$ new sterile microfuge tube for $10 \mathrm{PCR}$.

Then $2.5 \mu 1$ of each OPA 19and OPC 1 primer was added in each PCR tube.

Mixture was spin at $12000 \mathrm{rpm}$ for $2 \mathrm{~min}$ in tube.

Sterile microcentrifuge PCR tubes was numbered and placed on PCR tube stand.

$0.5 \mu 1$ of DNA was added to each PCR tube followed by $24.5 \mu \mathrm{l}$ master mix.

The samples were mixed by spin to bring down the content of tube.

PCR was run on the programmable thermal cycler with the following reactions

\section{Results and Discussion}

\section{Collection of sample}

The banana variety used in this study was G9. Five banana plant samples we used for this experiment. We analysed the five samples for clonal fedility and genetic analysis of tissue culture raised banana (musa spp.) plant (Fig. 1).

\section{Genomic DNA quality confirmation}

The Sambrook et al., (1989) CTAB protocol was used to isolate DNA from all the collected samples. The extent of degradation reduced significantly when the samples were ground in the extraction buffer PCR for DNA samples selected randomly gave expected 700 bp amplicons as shown in confirming that the DNA was intact and of PCR-quality.

The RNase treatment step associated with most DNA isolation procedures was omitted in this protocol for one good reason and confirmation of DNA on gel electrophoresis under U.V. Transilluminator and photographs was taken by gel documentation (Fig. 2).

\section{PCR amplification image in OPA-19 and OPC-1}

The amplification products were resolved by electrophoresis on a $1 \%$ agarose gel with Ethidium bromide and visualized under UV. The presence and absence of bands between samples was scored and data were transcribed.

Screening of the 1 mother and 4 daughter subculture levels revealed that banding profiles obtained with OPA 19, OPC 1, primers were enough to show similarities between mother and daughter plants. There is no variation in mother and daughter plant. The results indicated that the RAPD technique is effective to develop genotype-specific banding patterns valuable for cultivar identification (Fig. 3 and 4). 
Table.1 C-TAB buffer (Extraction buffer)

\begin{tabular}{|c|c|c|}
\hline $\begin{array}{c}\text { Sr. } \\
\text { No. }\end{array}$ & Chemical & \\
\hline 1 & C-TAB & $1 \mathrm{~mm}$ \\
\hline 2 & $1 \mathrm{M}$ Tris HCL & $5 \mathrm{ml}$ \\
\hline 3 & $0.5 \mathrm{M} \mathrm{EDTA}$ & $2 \mathrm{ml}$ \\
\hline 4 & $5 \mathrm{M} \mathrm{Nacl}$ & $10 \mathrm{ml}$ \\
\hline 5 & pvp (polyvinylpyrrolidone) & $0.5 \mathrm{gm}$ \\
\hline 6 & SDW & $33 \mathrm{ml}$ \\
\hline & Total & $50 \mathrm{ml}$ \\
\hline
\end{tabular}

Table.2 PCR amplification RAPD profile analysis

\begin{tabular}{|c|c|c|c|}
\hline $\begin{array}{c}\text { Sr. } \\
\text { No. }\end{array}$ & Primer Name & Primer Sequence & $\begin{array}{c}\text { Annealing } \\
\text { Temperature }\end{array}$ \\
\hline 1 & OPA-19 & $5^{\prime}$ 'CAAACGTCGG-3' & $34^{\circ} \mathrm{C}$ \\
\hline 2 & OPC-1 & $5^{\prime}$-TTCGAGCCA-3' & $35^{\circ} \mathrm{C}$ \\
\hline
\end{tabular}

Table.3 The reagent used for $1 \mathrm{x}$ of $25 \mu \mathrm{l}$ PCR reaction

\begin{tabular}{|c|c|c|}
\hline $\begin{array}{l}\text { Sr. } \\
\text { No. }\end{array}$ & Master mix component & $\begin{array}{c}\text { Quantity (1x of } 25 \mu \mathrm{l} \text { PCR } \\
\text { reaction) }\end{array}$ \\
\hline 1 & 10x Assay buffer & $2.5 \mu 1$ \\
\hline 2 & $\mathrm{MgCl} 2$ & $1 \mu \mathrm{l}$ \\
\hline 3 & DNTPs & $1 \mu \mathrm{l}$ \\
\hline 4 & Primer & $2.5 \mu 1$ \\
\hline 5 & Tag DNA polymerase & $0.2 \mu 1$ \\
\hline 6 & Sterile distilled water & $17.3 \mu \mathrm{l}$ \\
\hline & Total & $24.5 \mu \mathrm{l}$ \\
\hline 7 & Template DNA & $0.5 \mu 1$ \\
\hline & Total & $25 \mu 1$ \\
\hline
\end{tabular}

Table.4 Showing the quantity of DNA

\begin{tabular}{|c|c|c|}
\hline Sr. No $(\mathrm{ng})$ & Sample & Concentration \\
\hline 1 & Mother & 220 \\
\hline 2 & Daughter & 250 \\
\hline 3 & Daughter & 150 \\
\hline 4 & Daughter & 240 \\
\hline 5 & Daughter & 250 \\
\hline
\end{tabular}


Fig.1 Mother plant of banana (1) and daughter plants 2, 3, 4 and 5

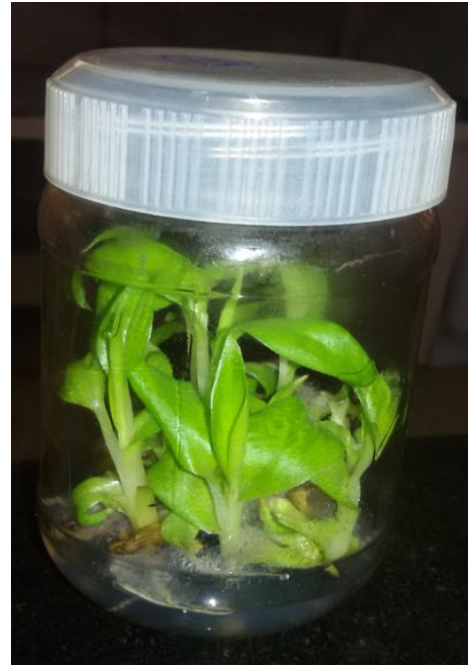

Mother Plant

1

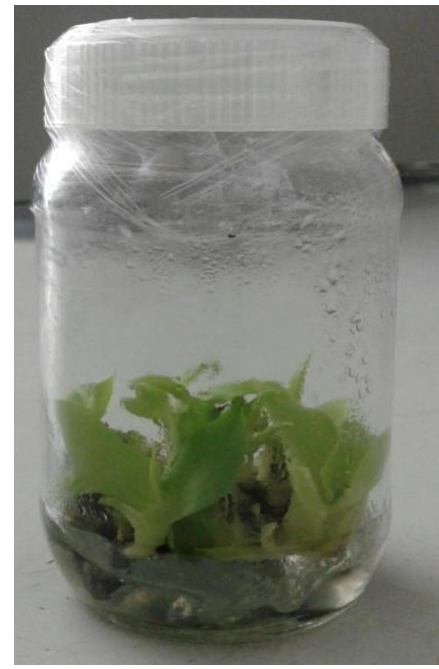

Daughter Plant

2

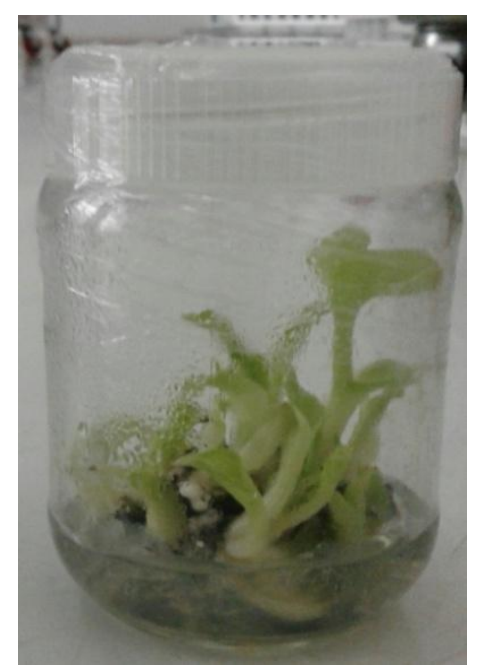

Daughter Plant 3

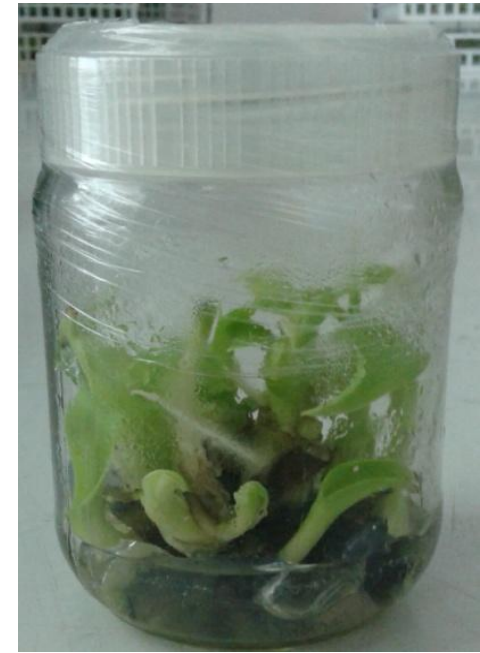

Daughter Plant 4

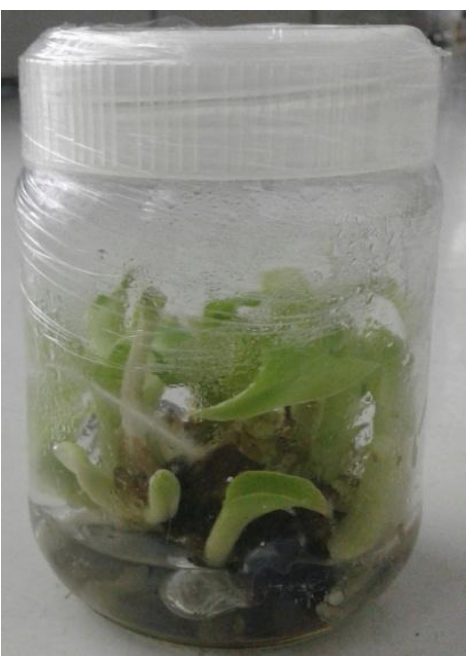

Daughter Plant

5

Fig.2 Quantification of DNA sample on gel electrophoresis

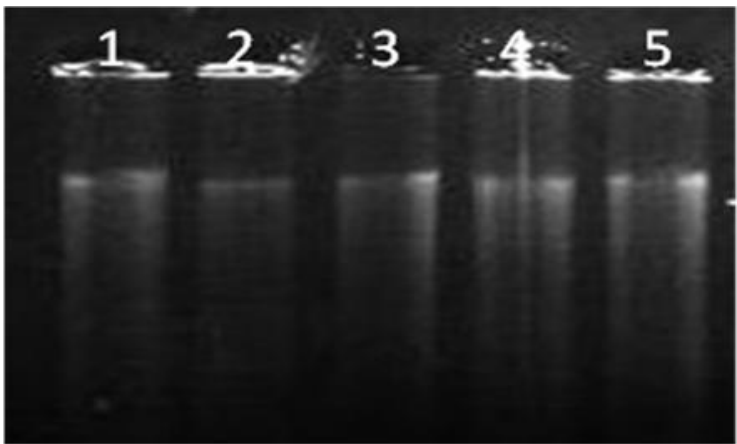


Fig.3 PCR for Banana samples with primer set OPA-19



Fig.4 PCR for Banana samples with primer set OPC-1

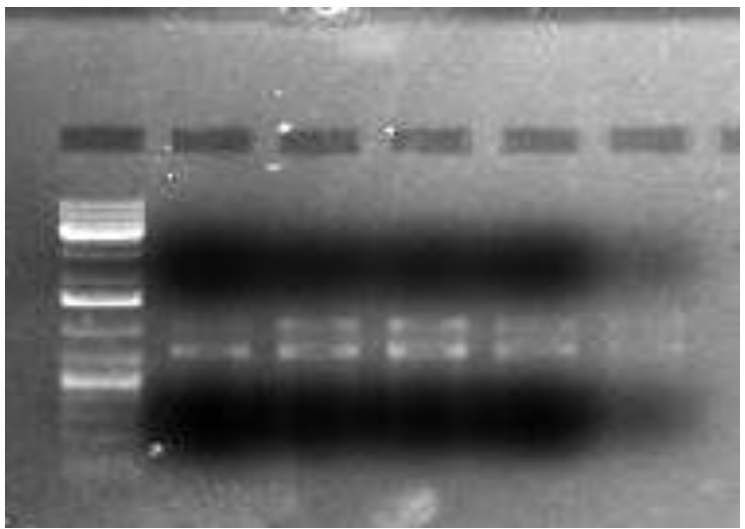

RAPD markers to identify and assess the level of clonal fedility and genetic analysis of tissue culture banana raised plant. They have confirmed since RAPD technique does not require previous DNA sequence information and uses very small quantity of DNA, it is considered as one of the most widely used techniques for genetic analysis studies.

Genetic molecular markers are considered to be reliable in monitoring variability in the DNA sequences of the plants (Piña-Escutia et al., 2010, Zerihun et al., 2009). Several authors have applied the RAPD technique to investigate the genetic variability and found it to be very efficient and reliable (Brown et al., 1993). The results obtained from RAPD analysis were compared with those obtained with restriction fragment length polymorphism (RFLP) and isozymes (Sabir et al., 1992) and found no difference in them. Screening of the 1 mother and 4 daughter subculture levels revealed that banding profiles obtained with OPA 19, OPC 1, primers were enough to show similarities between mother and daughter plants. There is no variation in mother and daughter plant.

The results indicated that the RAPD technique is effective to develop genotypespecific banding patterns valuable for cultivar identification. RAPD markers to identify and assess the level of clonal fedility and genetic analysis of tissue culture banana raised plant. They have confirmed since RAPD technique does not require previous DNA sequence 
information and uses very small quantity of DNA, it is considered as one of the most widely used techniques for genetic analysis studies.

In conclusion, our results showed that the 1 mother and 4 daughter subculture levels revealed that banding profiles obtained with Primer OPA 19, OPC 1 were show similarities between mother and daughter plants.

There is no variation in mother and daughter plant. The RAPD technique is effective to develop genotype-specific banding patterns valuable for cultivar identification. Molecular analysis using RAPD's can be applied to assess the clonal fidelity of plants derived invitro on an industrial scale as part of crop improvement programs (Table 1-4).

With the primer OPA-19 and OPC-1 amplified 1 mother and 4 daughter subculture are showed polymorphic bands is seen range of 500bp to $1000 \mathrm{pb}$. Our results demonstrate that molecular analysis using RAPD's can be applied to assess the clonal fidelity of plants derived In vitro on an industrial scale as part of crop improvement programs.

\section{References}

Brown, P.T., F.D. Lang, E. Kranz and H. Lörz. 1993. Analysis of single protoplasts and regenerated plants by PCR and RAPD technology. Mol. Gen. Genet., 237: 311-317.

Gopalan C, Rama sastri B.V Balasubramanian, S.C, 2002. Nutritive value of Indian foods, National institute of Nutrition, Hyderabad.

Sabir, A., H.J. Newbury, G. Todd, J. Catty and B.V. Ford-Lloud. 1992. Detection of genetic stability using isozymes and RFLPs in beet plants regenerated In vitro. Theor Appl Genet., 84: 113-117.

Sambrook et al., 1989.The DNA isolated would contain RNA as contaminant and was hence purified by treatment with RNase and further precipitated

Welsh J, McClelland M (1990) Fingerprinting genomes using PCR with arbitrary primers. Nucleic Acids Res 18: 72137218.

Williams JGK, Kubelik AR, Livak KJ, Rafalski JA, Tingey SV (1990) DNA polymorphisms amplified by arbitrary primers are useful as genetic markers. Nucleic Acids Res 18: 6531-6535.

\section{How to cite this article:}

Jotshana Manik Maske, Amol Dadarao Sable and Prashant Bhausaheb Kardile. 2018. Assessment of Clonal Fidelity and Genetic Analysis of Tissue Culture Raised Banana (Musa spp.) Plant. Int.J.Curr.Microbiol.App.Sci. 7(04): 2552-2558.

doi: https://doi.org/10.20546/ijcmas.2018.704.292 